\title{
ДОГОВІР ПРО НАДАННЯ ТУРИСТИЧНИХ ПОСЛУГ: ПОНЯТІЙНО-КАТЕГОРІАЛЬНИЙ АПАРАТ І ПРАВОВА ПРИРОДА
}

Андрусів У. Б.

Наукову статтю присвячено розв'язанню науково-прикладної проблеми вдосконалення понятійно-категоріального апарату договору про надання туристичних послуг. Проаналізовано доктринальні підходи до таких категорій, як «туристична послуга», «туристичне обслуговування», «туристичний продукт». Автор обгрунтовує необхідність закріплення в законодавстві дефініції терміна «договір про надання туристичних послуг». Розкрито правову природу договору. Досліджено електронну форму договору, зроблено висновок про неможливість укладення договору у формі ваучера.

Ключові слова: туристичний продукт, туристична послуга, туристичне обслуговування, договір про надання туристичних послуг, турист, туроператор.

Научная статья посвящена решению научно-прикладной проблемы совершенствования понятийно-категориального апnарата договора на оказание туристских услуг. Проанализированы доктринальные подходы к таким категориям, как "туристская услуга», «туристское обслуживание», «туристский продукт». Автор приходит к выводу о необходимости закрепления в законодательстве дефиниции термина «договор на оказания туристских услуг». Раскрыто правовую природу договора. Исследована электронная форма, сделан вывод о невозможности заключе ния договора в форме ваучера.

Ключевые слова: туристский продукт, туристская услуга, туристское обслуживание, договор на оказания туристских услуг, турист, туроператор.

The scientific article is devoted to solving the scientifically applied problem of improving the conceptual and categorical apparatus of the agreement on rendering of tourist services and exploring its legal nature.

The doctrinal approaches of such categories as "tourist service" and "tourist product" are analysed. It is substantiated that the "tourist product" cannot be the subject of agreement on rendering of tourist services. Etymologically, the term "product" includes works, goods and services; however, the subject of such agreement is only services. It is proposed to amend the Law of Ukraine "On Tourism", replacing the category "tourist product" with "tourist service". The essence and content of the concept of "tourist service" are revealed.

Author noticed that the term "integrated tourist service" is inappropriate, because the tourist service is already a combination of two or more services.

Emphasis is placed on terminological inaccuracies in the application of the regulatory designation of the agreement on rendering of tourist services. The criteria for the delimitation of the agreement on rendering of tourist services from the service contracts are defined. The necessity of changing the name of this agreement to "agreement on rendering of tourist services" is substantiated and the author's definition of this term is proposed.

Based on generalization of theoretical researches, analysis of current legislation of Ukraine, the legal nature of the agreement on rendering of tourist services is revealed. It is established that such agreement is consensual, paid and bilateral.
The agreement on rendering of tourist services is a contract of adhesion and a public contract in the case of booking by client tourist service pre-formed by the tour operator. Given that the services under this agreement are provided not by tour operators but by direct contractors, this contract is recognized as a contract performed by third parties.

Particular attention is paid to the form of agreement on rendering of tourist services. It was deduced that it was impossible to conclude an agreement on rendering of tourist services in the form of a voucher, because it does not contain the necessary essential conditions stipulated by a special law.

Key words: tourist product, tourist service, tourist service, agreement on rendering of tourist services, tourist, tour operator.

Постановка проблеми та їі актуальність. За останні десятиліття ринок туристичних послуг набув небувалого розвитку. Туризм $\epsilon$ невіддільною частиною динамічного життя сучасної людини. Відтак усе більшого значення набуває створення ефективної та дієвої системи охорони прав споживачів туристичних послуг.

Ключовим цивільно-правовим інструментом охорони прав учасників туристичних правовідносин виступає договір про надання туристичних послуг. Такий договір $є$ правовим засобом досягнення основної мети туризму - забезпечення туристів якісними туристичними послугами під час здійснення подорожі.

Суттєвими перепонами на шляху створення дієвих правових засобів захисту прав учасників туристичних правовідносин $\epsilon$ відсутність ефективного правового регулювання туристичної діяльності, недостатня розробленість на законодавчому рівні понятійно-категоріального апарату договору про надання туристичних послуг, що й зумовлює необхідність детальнішого аналізу обраної проблематики.

Аналіз останніх досліджень і публікацій. На доктринальному рівні договірні відносини у сфері туризму були предметом наукових розвідок таких ученихцивілістів, як Я.В. Вольвач, В.І. Гостюк, М.М. Гудима, Л.О. Дзюбенко, С.В. Зав'ялова, Н.В. Камінська, А.С. Кусков, Н.В. Сірик, М.В. Семенова, Н.В. Федорченко, С.А. Чернякова, Р.І. Яворський. Проте низка питань, пов'язаних із визначенням основних категорій договору про надання туристичних послуг, розкриттям його правової природи, залишилися поза увагою наукової спільноти або все ще $є$ дискусійною.

Метою статті $\epsilon$ проведення аналізу понятійно-категоріального апарату договору про надання туристичних послуг, розкриття правової природи та особливих вимог до форми договору, а також напрацювання пропозицій щодо вдосконалення правового регулювання цих договірних відносин. 
Виклад основного матеріалу. Основним регулятором відносин, які виникають між туристом і суб'єктом туристичної діяльності, $\epsilon$ цивільно-правовий договір. Законодавець визначає це договірне зобов'язання як договір на туристичне обслуговування.

У законодавстві зарубіжних країн для позначення такого договору використовуються різні назви. Закон Республіки Білорусь «Про туризм» оперує терміном «договір про надання туристичних послуг» [1]. У Німецькому цивільному уложенні, як і в Законі України «Про туризм», цей договір іменується договором на туристичне обслуговування [2]. Директива 2015/2302/ $€ С$ ці відносини кваліфікує як договір про реалізацію пакетного туру [3].

У спеціальній літературі теж трапляються різні найменування договору, який опосередковує взаємовідносини між споживачем туристичної послуги та туроператором (турагентом). Наприклад, цей договір іменується як договір про надання туристичних послуг [4, с. 149; 5, с. 28], договір про надання послуг із туристичного обслуговування [6, с. 128; 7], договір про туристичне обслуговування [8, с. 35], договір про надання комплексу туристичних послуг [9, с. 168].

3'ясуємо, яке ж позначення відповідає суті та правовій природі договору, що укладається між туроператором (турагентом) і туристом або іншим замовником.

Відповідно до ст. 20 Закону України «Про туризм» за договором на туристичне обслуговування одна сторона (туроператор, який укладає договір безпосередньо або через турагента) зобов'язується надати за замовленням іншої сторони (туриста) комплекс туристичних послуг (туристичний продукт), а турист зобов'язується оплатити його [10]. Виникає питання: як співвідносяться між собою терміни «туристичний продукт» i «туристична послуга» і які дії становлять предмет договору?

Статтею 1 Закону України «Про туризм» регламентовано, що туристичний продукт - попередньо розроблений комплекс туристичних послуг, який поєднує не менше ніж дві такі послуги, що реалізується або пропонується для реалізації за визначеною ціною, до складу якого входять послуги перевезення, послуги розміщення та інші туристичні послуги, не пов'язані з перевезенням і розміщенням (послуги з організації відвідувань об'єктів культури, відпочинку та розваг, реалізації сувенірної продукції тощо) [10].

Незважаючи на нормативне закріплення визначення туристичного продукту, науковці по-різному трактують зазначену категорію, зокрема, як: товар або право, призначене для реалізації туристу; комплекс туристичних послуг; комплекс послуг, робіт і товарів [11, с. $133-$ 135]. Не викликає сумніву той факт, що туристу надаються послуги з перевезення, переміщення, харчування та інші послуги. Об'єднання туроператорами цих послуг в єдину послугу та її надання туристу не можуть змінити об'єкт цивільних прав і трансформувати послуги в товар (речове право) або роботу. Отже, туристський продукт не можна розглядати як товар, роботи або їх сукупність.

Для того, щоб з'ясувати, що являє собою туристичний продукт, звернемося до положень ст. 177 ЦК України, яка закріплює перелік об'єктів цивільних прав, тобто те, на що спрямовані права та обов'язки суб' єктів цивільних правовідносин. 3 аналізу цієї норми випливає, що законодавець не відносить ні туристичний, ні будь-який інший продукт до об'єктів цивільних прав.
За своїм змістом продукт - це речовий або інтелектуальний результат людської праці [12]. Тобто туристичний продукт має уречевлену форму та економічне підґрунтя.

Я.В. Вольвач доходить висновку, що «категорія «туристичний продукт» як лексично, так і за змістом не відповідає ні суті, ні правовій природі відносин із туристичного обслуговування» [6, с. 31-32]. Розвиваючи цю позицію, С.В. Зав'ялова пропонує взагалі відмовитися від поняття «туристичний продукт» [7]. Солідаризуючись із науковцями, вважаємо, що використання терміна «туристичний продукт» у туристичних правовідносинах $\epsilon$ необґрунтованим, оскільки продукт за своїм лексичним змістом матеріалізований і належить до об'єктів речового права, а отже, є результатом виконання певної роботи, тоді як туристичні послуги нематеріальні та підпадають під дію норм гл. 63 ЦК України, яка визначає загальні положення договорів про надання послуг.

Зобов'язання 3 надання туристичних послуг визначається самим фактом надання послуги, а не реалізації туристичного продукту, тому туристичний продукт не можна вважати предметом договору про туристичне обслуговування, яким $\epsilon$ певного роду дія або певна діяльність туроператора (туагента), спрямована на задоволення потреб фізичної особи, що здійснює подорож, тобто сама послуга.

Враховуючи викладене, на наше переконання, термін «туристичний продукт», що вживається в Законі України «Про туризм», необхідно виключити, замінивши його на більш обґрунтований термін «туристична послуга».

Однак на законодавчому рівні не закріплено дефініції поняття «туристична послуга». Пропонуємо під туристичною послугою розуміти дії або діяльність туроператора, спрямовані на формування комплексу послуг, що включає дві і більше послуги (перевезення, розміщення чи інші послуги, не пов'язані з перевезенням і розміщенням, у будь-якому їх поєднанні), та надання його за плату туристу або іншому замовнику на умовах, встановлених договором. Вважаємо за доцільне ст. 1 Закону України «Про туризм» доповнити цим поняттям.

У процесі дослідження нами з'ясовано, що предметом договірного зобов'язання, який визначає взаємовідносини між суб'єктом туристичної діяльності та туристом, $є$ діяльність туроператора, спрямована на надання туристичної послуги. Тому нормативне позначення договору терміном «туристичне обслуговування» видається необґрунтованим і не відповідає його суті. Обслуговування $\epsilon$ різноманітною діяльністю, що покликана задовольняти потреби фізичних та юридичних осіб. Обслуговування не обмежується наданням послуг, а включає передання товарів, виконання робіт.

3 огляду на це слушною вважаємо позицію науковців, що для визначення дій, спрямованих на задоволення потреб туриста під час подорожі, варто застосовувати термін «туристична послуга», а не «туристичне обслуговування», а отже, термін «обслуговування» не може відображатись у назві договору між суб'єктом туристичної діяльності, який надає туристичні послуги, та туристом унаслідок більш широкого його змісту $[13$, с. $28 ; 14$, с. $32 ; 15$, с. 149$]$.

Водночас важко погодитися з науковцями, які для позначення договору використовують поняття «комплекс туристичних послуг» [9, с. 168]. 
Договір про надання туристичних послуг встановлює лише одне зобов'язання, внаслідок якого туроператор бере на себе зобов'язання надати туристу весь комплекс послуг із розміщення, перевезення, харчування і т.п. Від кількості послуг, які надаються туроператором або безпосередніми виконавцями, юридична сутність договірного зобов'язання не змінюється.

Безперечно, туристична послуга має комплексний характер, включає в себе більше однієї послуги, проте предметом договору $є$ одна послуга з детальною характеристикою іiі складників, які перебувають у єдності та взаємозв'язку.

Отже, відносини між туроператором і туристом опосередковуються договором про надання туристичних послуг. Саме таке поняття необхідно закріпити в законодавстві.

Зосередимо увагу на правовій природі досліджуваного правочину. Договір про надання туристичних послуг $є$ консенсуальним, що випливає із самої природи туристичних послуг. Наданню послуг передує погодження туроператором (турагентом) i туристом (іншим замовником) усіх істотних умов та їх письмове оформлення, тобто укладення договору та його виконання не збігаються в часі.

Зважаючи на законодавчу презумпцію оплатності договорів, які опосередковують зобов'язання з надання послуг, досліджуваний договір має оплатний характер. Обидві сторони беруть на себе зобов'язання з метою отримання зустрічного майнового надання від контрагента: туроператор отримує обумовлену договором плату, а турист - туристичну послугу.

Наявність взаємокореспондуючих суб'єктивних прав та обов'язків в обох сторін дає змогу характеризувати договір про надання туристичних послуг як двосторонній (синалагматичний). Ця ознака має велике значення для правозастосовної практики, зокрема, у разі покладення на туроператора відповідальності за порушення договірних зобов'язань.

Переважно послуги за цим договором надають не туроператори, а інші суб'єкти, що забезпечують туристичну діяльність (готелі, перевізники), через що цей договір можна визнати договором, виконуваним третіми особами. Зазначене повною мірою корелюється з приписами ч. 2 ст. 902 ЦК України, якою регламентовано, що у випадках, встановлених договором, виконавець має право покласти виконання договору про надання послуг на іншу особу, залишаючись відповідальним у повному обсязі перед замовником за порушення договору [16].

Отже, у разі невиконання чи неналежного виконання зобов'язань із надання послуг туристу безпосередні виконавці, які не $\epsilon$ стороною договору про надання туристичних послуг, не несуть відповідальності перед туристом, оскільки забезпечення надання туристам послуг - це обов'язок туроператора, і саме на нього покладається відповідальність, незалежно від того, хто повинен був надати чи надавав ці послуги.

Проте, як свідчить судова практика, туроператори намагаються уникнути відповідальності за дії третіх осіб. Для наочного прикладу звернемося до справи 465/6235/15-ц за позовом ОСОБА_1 до ДП «А.Е.Т.ДЖОІН АП!», особи ФОП ОСОБА_2 про стягнення збитку та відшкодування моральної шкоди.

Позов мотивовано тим, що позивач уклав договір про надання туристичних послуг - організації турис- тичної поїздки за маршрутом Львів-Туреччина-Львів 3 турагентом ФОП ОСОБА_2 - Туристичною агенцією «Max Travel», що діяв від імені та за дорученням туроператора ДП «А.Е.Т.ДЖОІН АП!». Відповідно до умов договору відповідач узяв на себе зобов'язання надати туристичну послугу, яка включала проживання в готелі «Alperbey Hotel 3*». Проте позивача разом із його сім'єю, незважаючи на їхні заперечення, поселили в готелі «Rosella Suite Hotel».

Відповідач позов не визнав, зазначивши, що ним повністю виконано взяті на себе зобов'язання. При цьому він стверджував, що з незалежних від нього причин, а саме у зв' язку з перепродажем готелем «Alperbey Hotel 3* номерів, позивача разом із сім'єю було розміщено в готелі «Rosella Suite Hotel».

Вирішуючи спір, суд, керуючись ст. ст. 20, 30, 32 Закону України «Про туризм», ухвалив відшкодувати різницю у вартості замовленого та фактичного наданого туристичного продукту та моральну шкоду [17].

Варто зазначити, що спеціальне законодавство, яке визначає засади здійснення туристичної діяльності, не містить положень про те, що туроператор, як сторона договору про надання туристичних послуг, $є$ відповідальним за обсяг та якість послуг, які надаються безпосередніми виконавцями. 3 метою посилення охорони прав та інтересів споживачів туристичних послуг уважаємо за доцільне усунути цю прогалину, доповнивши ч. 1 ст. 24 Закону України «Про туризм» абз. 10 такого змісту: «Туроператор має право покласти виконання договору про надання туристичних послуг частково або у повному обсязі на інших суб'єктів підприємницької діяльності, що надають послуги з тимчасового розміщення, харчування, екскурсійних, розважальних та інших туристичних послуг, залишаючись відповідальним перед туристом за недотримання умов договору».

Договір про надання туристичних послуг, які заздалегідь сформовані туроператором, є публічним договором. Якщо ж туристична послуга надається за індивідуальним завданням (замовленням) туриста, за таких обставин договір не підпадає під ознаки публічного.

Публічний характер договору про надання туристичних послуг зумовлює деякі особливості його регулювання. Туроператор зобов'язаний вступати в договірні відносини з будь-якою фізичною або юридичною особою, яка до нього звернеться. Пропозиція надання туристичних послуг, що звернена до невизначеного кола осіб та оприлюднена у вигляді реклами, буклетів, каталогах, інших описах, і яка містить усі істотні умови договору, як слушно зазначається у літературі, визнається публічною офертою [18, с. 88].

Ціна туристичних послуг встановлюється однаковою для всіх туристів, за винятком випадків, коли законом встановлено пільги для певних категорій споживачів туристичних послуг, до прикладу, щодо сплати туристичного збору, якщо цей платіж включається до ціни договору. Відмова туроператора (турагента) від укладення договору допускається лише у разі, якщо у нього відсутня можливість надати туристичні послуги.

Досліджуваний договір здебільшого укладається в порядку, передбаченому для договорів приєднання. Якщо формування туристичної послуги та подальша ii реалізація туристу здійснюються на умовах, попередньо розроблених туроператором, договір про надання туристичних послуг є договором приєднання. 
Зміст (умови) такого договірного зобов' язання визначається одноосібно туроператором у стандартних договорах. Натомість турист не бере участі у визначенні умов договору, а лише дає згоду на запропонований туроператором варіант договору загалом. Нам імпонує позиція М.М. Гудими, який наголошує, що така згода повинна бути беззастережною [19, с. 83]. Отже, умови договору розробляються наперед однією зі сторін - туроператором, а інша сторона - турист або повністю приймає ці умови, або відхиляє їх.

3'ясувавши понятійно-категоріальний апарат і характерні ознаки договору про надання туристичних послуг, сформулюємо дефініцію цієї договірної конструкції.

За договором про надання туристичних послуг одна сторона (туроператор, який діє безпосередньо або через турагента) зобов' язується надати іншій стороні (туристу або іншому замовнику) самостійно або із залученням третіх осіб туристичні послуги відповідно до мети подорожі та на умовах, установлених договором, а турист (інший замовник) зобов'язується оплатити ці послуги.

Відповідно до вимог ст. 20 Закону України «Про туризм» договір про надання туристичних послуг укладається в письмовій чи електронній формі.

Вважаємо за потрібне зосередити увагу на електронній формі договору про надання туристичних послуг, оскільки залишається відкритим питання, який зміст законодавець вкладає в «електронну форму» розглядуваного правочину.

3 аналізу приписів ст. 205 ЦК України вбачається, що законодавець закріпив дихотомічний поділ форм договорів на усну та письмову, а електронна форма $\epsilon$ різновидом письмової. Цей висновок узгоджується з положеннями абз. 2 ч. 2 ст. 639 ЦК України, у якому передбачено, що, якщо сторони домовилися укласти договір за допомогою інформаційно-телекомунікаційних систем, він вважається укладеним у письмовій формі [16].

Однією з нормативних вимог, яка висувається до письмової (електронної) форми договору, є скріплення його підписами сторін. Ст. 12 Закону України «Про електронну комерцію» регламентовано, що моментом підписання електронного правочину $\epsilon$ використання: електронного підпису або електронного цифрового підпису; електронного підпису одноразовим ідентифікатором; аналога власноручного підпису [20].

Відповідно до Регламенту Європейського Союзу № 910/2014 електронний підпис - дані в електронній формі, які приєднуються або логічно пов'язуються 3 іншими електронними даними і використовуються підписувачем як підпис [21]. Ця дефініція включає і так званий оцифрований підпис, під яким фахівці розуміють підпис на папері, який потім відсканували та зберегли його зображення для подальшого використання [22]. Відтак сканований власноручний підпис, який зазвичай і використовується контрагентами договору про надання туристичних послуг, можна вважати електронним.

Зазначимо, що на практиці учасники туристичних правовідносин під час укладення договору про надання туристичних послуг практично не використовують електронну форму. Це зумовлено тим, що лише незначна кількість туристів отримала електронний цифровий ключ, а використання відсканованого власноручного підпису утруднює ідентифікацію підписантів.
Крім того, у Законі України «Про туризм» закріплена така форма письмового договору на туристичне обслуговування, як ваучер. Відповідно до Інструкції про порядок оформлення ваучера на надання туристичних послуг та його використання, ваучер - документ, який $\epsilon$ підставою і гарантією для отримання туристом оплаченої послуги або комплексу послуг у суб'єкта туристичної діяльності, що надає послуги [23].

У ч. 2 ст. 23 Закону України «Про туризм» перелічено дані, які повинні міститися в договорі про надання туристичних послуг, укладеному шляхом видачі ваучеру [10]. Здійснивши порівняльний аналіз контенту цих даних і переліку істотних умов, який передбачений ч. 4 ст. 20 Закону України «Про туризм», доходимо висновку, що ваучер не містить усіх істотних умов, необхідних для укладення договірного зобов'язання з надання туристичних послуг.

3 приписів ст. 638 ЦК України випливає, що договір уважається укладеним, якщо сторони в належній формі досягнули згоди з усіх істотних умов договору [16]. 3 огляду на це нам імпонує позиція науковців, які не відносять ваучер до письмової форми договору, оскільки ці категорії не рівнозначні [19, с. 85; 24 , с. $13 ; 25$, с. 166] Право туриста на туристичні послуги виникає лише на підставі договору, а ваучер - це документ, який підтверджує оплату туристичної послуги та ідентифікує туриста (групу туристів) перед суб'єктами туристичної діяльності, які безпосередньо надають послуги з перевезення, тимчасового розміщення, харчування і т.п.

У результаті проведеного дослідження можемо зробити такі висновки.

Договір про надання туристичних послуг є основним регулятором взаємовідносин, які складаються між туроператором і туристом. Предметом договору $\epsilon$ діяльність туроператора, спрямована на надання туристичної послуги, а не на реалізацію туристичного продукту, тому запропоновано внести зміни до Закону України «Про туризм», замінивши категорію «туристичний продукт» на поняття «туристична послуга».

Під договором про надання туристичних послуг слід розуміти договір, за яким одна сторона (туроператор, який діє безпосередньо або через турагента) зобов'язується надати іншій стороні (туристу або іншому замовнику) самостійно або із залученням третіх осіб туристичні послуги відповідно до мети подорожі та на умовах, установлених договором, а турист (інший замовник) зобов'язується оплатити ці послуги. Саме таке позначення договору та наведену дефініцію необхідно закріпити в законодавстві, виключивши термін «договір на туристичне обслуговування».

За правовою природою договір про надання туристичних послуг $\epsilon$ консенсуальним, оплатним, двостороннім і договором, виконуваним третіми особами. У разі замовлення туристом заздалегідь сформованої туроператором туристичної послуги цей договір також $\epsilon$ публічним і договором приєднання.

Обґрунтовано неможливість укладення договору про надання туристичних послуг у формі ваучера, оскільки він не містить істотних умов, необхідних для укладення договірного зобов'язання з надання туристичних послуг. 


\section{Література}

1. 0 туризме : Закон Республики Беларусь от 25 ноября 1999 г. № 326-3. URL: https://kodeksy-by.com/zakon_rb_o_ turizme.htmhttps://kodeksy-by.com/zakon_rb_o_turizme. $\mathrm{htm}$ (дата звернення: 15.02.2020).

2. Гражданское уложение Германии. URL: http: / / oceanlaw.ru/wp-content/uploads/2018/02/1900.pdf (дата звернення: 16.02.2020).

3. Директива (ЄC) 2015/2302 Європейського парламенту та Ради ЄС від 25 ноября 2015 г. про пакетні тури та пов'язані 3 ними туристичні послуги. URL: http: / / eur-lex.europa.eu/legal-content/EN/TXT/?qid=1 504626811216\&uri=CELEX:32015L2302 (дата звернення: 15.02.2020).

4. Федорченко Н.В. Роль договору у сфері надання туристичних та готельних послуг. Приватне право і підприємництво. 2018. Вип. 18. С. 148-152.

5. Камінська Н.В. Щодо питання класифікації договорів у туристичній сфері. Підприємництво, господарство і право. 2017. № 3. С. 27-30.

6. Вольвач Я.В. Туристические услуги как объект гражданских правоотношени : монография. Москва : Норма; Инфра-М, 2012. 128 с.

7. Завьялова С.В. К проблеме определения правовой природы договора о реализации туристского продукта. Теория и практика общественного развития. 2017. № 10. URL: https://cyberleninka.ru/article/n/k-problemeopredeleniya-pravovoy-prirody-dogovora-o-realizatsiituristskogo-produkta (дата звернення: 16.02.2020).

8. Соколова Н.А. Туризм в Российской Федерации: правовое регулирование : учеб. пособие. Москва : ВолтерсКлувер, 2010. 224 с.

9. Семенова М.В. Аналіз договору про надання комплексу туристичних послуг і визначення його істотних умов. Теорія та практика адаптації законодавства України до законодавства $€ C$ : матеріали Міжнародної науково-практичної конференції, 8 червня 2018 р. Київ : Видавничий дім «Гельветика», 2018. С. 167-171.

10. Про туризм : Закон України від 15 вересня 1995 р. № 324/95-ВР. Відомості Верховної Ради України. 1995. № 31. Ст. 24.

11. Сирик Н.В., Кусков А. С. Правовая природа договора о реализации туристского продукта. Вісник Харківського національного університету імені В.Н. Каразіна. Серія : Міжнародні відносини. Економіка. Країнознавство. Туризм. 2013. № 1042. Вип. 1. С. 132-137.

12. Продукт (економіка). URL: https://uk.wikipedia. org/wiki (дата звернення: 16.02.2020).

13. Камінська Н.В. Щодо питання класифікації договорів у туристичній сфері. Підприємництво, господарство і право. 2017. № 3. С. 27-30.
Проблеми цивільного та господарського права

14. Гудима М.М. Захист прав споживачів за договором про надання туристичних послуг : дис. ... канд. юрид. наук : 12.00.03. Київ, 2012. 247 с.

15. Федорченко Н.В. Роль договору у сфері надання туристичних та готельних послуг. Приватне право і підприємництво. 2018. Вип. 18. С. 148-152.

16. Цивільний кодекс України: Закон України від 16 січня 2003 р. № 435-IV. Відомості Верховної Ради України. 2003. №№ 40-44. Ст. 356.

17. Рішення Франківського районного суду м. Львова від 24 травня 2016 р. у справі 465/6235/15-ц. URL: http://reyestr.court.gov.ua/Review/57954437 (дата звернення: 16.02.2020).

18. Чернякова С.А. Отдельные аспекты правового регулирования туризма в России. Сервис в России и за рубежом. 2019. Т. 13. Вып. 3. С. 87-100.

19. Гудима М.М. Тонкощі порядку укладення договору про надання туристичних послуг. Актуальні проблеми вдосконалення чинного законодавства України. 2014. Вип. 35. С. 78-87.

20. Про електронну комерцію: Закон України від 3 вересня 2015 р. № 675-VIII. Відомості Верховної Ради. 2015. № 45. Ст. 410.

21. Регламент Європейського Союзу № 910/2014 Європейського Парламенту і Ради від 23 липня 2014 р. про електронну ідентифікацію та довірчі послуги для електронних транзакцій в межах внутрішнього ринку. Офіційний вісник EC. L 257/73. URL: https://czo.gov.ua/download/ docs/reg_910_2014_ua.pdf (дата звернення: 16.02.2020).

22. Чеславський О. Що таке електронний (цифровий) підпис. КиевVласть. 29.10.2019. URL: http: / / kievvlast.com.ua/mind/shho-take-elektronnijtsifrovij-pidpis (дата звернення 17.02.2020).

23. Інструкція про порядок оформлення ваучера на надання туристичних послуг та його використання. Затверджено Наказом Держтурадміністрації України від 6 червня 2005 р. № 50. URL: https://zakon.rada.gov.ua/ laws/show/z0765-05 (дата звернення 16.02.2020).

24. Яворський Р.І. Договір про надання туристичних послуг : автореф. дис. ... канд. юр. наук : 12.00.03. Львів, 2015. 20 c.

25. Гостюк В.І. Договірне регулювання відносин у сфері надання туристичних послуг. Часопис Київського університету права. 2014. № 1. С. 163-168.

Андрусів У. Б., кандидат юридичних наук, доцент, доцент кафедри цивільно-правових дисциплін Львівського державного університету внутрішніх справ 